\title{
Modulatory Effect of Byrsonima basiloba Extracts on the Mutagenicity of Certain Direct and Indirect-Acting Mutagens in Salmonella typhimurium Assays
}

\author{
Walclecio de Moraes Lira, ${ }^{1}$ Fabio Vieira dos Santos, ${ }^{1, *}$ Miriam Sannomiya, ${ }^{2}$ \\ Clenilson Martins Rodrigues, ${ }^{2}$ Wagner Vilegas, ${ }^{2}$ and Eliana Aparecida Varanda ${ }^{1}$ \\ ${ }^{1}$ Department of Biological Sciences, Faculty of Pharmaceutical Sciences of Araraquara, \\ São Paulo State University, Rodovia Araraquara-Jaú; and ${ }^{2}$ Chemical Institute of Araraquara, \\ São Paulo State University, Araraquara, São Paulo, Brazil
}

\begin{abstract}
Byrsonima basiloba A. Juss. species is a native arboreal type from the Brazilian "cerrado" (tropical American savanna), and the local population uses it to treat diseases, such as diarrhea and gastric ulcer. It belongs to the Malpighiaceae family, and it is commonly known as "murici." Considering the popular use of B. basiloba derivatives and the lack of pharmacological potential studies regarding this vegetal species, the mutagenic and antimutagenic effect of methanol $(\mathrm{MeOH})$ and chloroform extracts were evaluated by the Ames test, using strains TA97a, TA98, TA100, and TA102 of Salmonella typhimurium. No mutagenic activity was observed in any of the extracts. To evaluate the antimutagenic potential, direct and indirect mutagenic agents were used: 4 nitro-o-phenylenediamine, sodium azide, mitomycin $\mathrm{C}$, aflatoxin $\mathrm{B}_{1}$, benzo[ $[a]$ pyrene, and hydrogen peroxide. Both the extracts evaluated showed antimutagenic activity, but the highest value of inhibition level (89\%) was obtained with the $\mathrm{MeOH}$ extract and strain TA100 in the presence of aflatoxin $\mathrm{B}_{1}$. Phytochemical analysis of the extracts revealed the presence of $n$-alkanes, lupeol, ursolic and oleanolic acid, (+)-catechin, quercetin-3- $O$ - $\alpha$-L-arabinopyranoside, gallic acid, methyl gallate, amentoflavone, quercetin, quercetin-3- $O$ - $\left(2^{\prime \prime}-O\right.$-galloyl)- $\beta$-D-galactopyranoside, and quercetin-3-O-(2"-O-galloyl)- $\alpha$-L-arabinopyranoside.
\end{abstract}

KEY WORDS: • Ames test • antimutagenic • Byrsonima • mutagenic

\section{INTRODUCTION}

C OMPOUNDS CAPABLE of promoting mutation are found in our daily diet, as well as in air and water pollution, drinks, medications, and solar radiation. It is known that mutations are a major factor for the onset of cancer. Chemoprevention, i.e., prevention against cancer development by chemical substances that act as antimutagenic agents and present the capacity to interact with mutagenic compounds or their metabolites and reduce their effects, is one possible alternative for preventing cancer. ${ }^{1}$

Exposure to environmental mutagenic substances can influence not only the development of cancer, but also cardiovascular and neurodegenerative diseases. ${ }^{2-4}$

The species Byrsonima basiloba A. Juss., belonging to the Malpighiaceace family, is commonly known as "murici," and the local population uses its derivative prod-

\footnotetext{
Manuscript received 14 August 2007. Revision accepted 24 October 2007.
}

Address reprint requests to: Eliana Aparecida Varanda, Department of Biological Sciences, Faculty of Pharmaceutical Sciences of Araraquara, São Paulo State University, Rodovia Araraquara-Jaú, Km 1, 14801-902, SP, Brazil, E-mail: varandae@fcfar.unesp.br

*Present address: Research and Development Institute, Vale do Paraíba Universtity, UNIVAP, São José dos Campos, SP, Brazil. ucts for the treatment of diseases, such as diarrhea and gastric ulcer. However, no effective biological activity has been detected up to now, since only a few studies have been performed regarding this species. Previously, our group reported the antidiarrheal activity of methanolic and hydromethanolic extracts obtained from the leaves of Byrsonima cinera (now formally documented as $B$. basiloba) determined by intestinal motility in Swiss mice. This assay showed a significant reduction in gastrointestinal motility of both extracts evaluated. A chemical study of the methanolic extract of this species revealed (+)-catechin and quercetin-3-O- $\alpha$-L-arabinopyranoside. ${ }^{6}$

Other species of the Byrsonima genus are characterized by the presence of sulfonoglycolipids, phytosterols, triterpenes, aromatic esters, amino acids, proanthocyanidins, and flavonoids. ${ }^{7}$

Considering the popular use of $B$. basiloba, as well as the limited number of pharmacological potential studies regarding this botanical species, the mutagenic and antimutagenic effects of methanol $(\mathrm{MeOH})$ and chloroform $\left(\mathrm{CHCl}_{3}\right)$ extracts were evaluated using different mutagens with direct (sodium azide [SAZ], mitomycin C (MMC), hydrogen peroxide, and 4-nitro- $o$-phenylenediamine $[\mathrm{NPD}])$ and indirect \{aflatoxin $\mathrm{B}_{1}(\mathrm{AFL})$, benzo $[a]$ pyrene $(\mathrm{B}[a] \mathrm{P})$, and hydrogen 
peroxide $\left(\mathrm{H}_{2} \mathrm{O}_{2}\right)$ \} action. This study was based on the Salmonella reversion assay, which is widely used for the detection of antimutagenic agents, especially those present in plant extracts. ${ }^{8-11}$

\section{MATERIALS AND METHODS}

\section{Chemicals}

Dimethyl sulfoxide (DMSO), $\mathrm{MeOH}, \mathrm{CHCl}_{3}$, nicotinamide adenine dinucleotide phosphate sodium salt, D-glucose-6-phosphate disodium salt, magnesium chloride, L-histidine monohydrate, D-biotin, SAZ, 2-aminoanthracene, NPD, MMC, B $[a] \mathrm{P}$, and AFL were purchased from Sigma Chemical Co. (St. Louis, MO). Oxoid nutrient broth no. 2 (Oxoid, London, UK) and Difco (Detroit, MI) Bacto Agar were used as bacterial media. D-Glucose, magnesium sulfate, citric acid monohydrate, anhydrous dibasic potassium phosphate, sodium ammonium hydrogen phosphate, monobasic sodium phosphate, dibasic sodium phosphate, sodium chloride, and $\mathrm{H}_{2} \mathrm{O}_{2}$ were purchased from Merck (Whitehouse Station, NJ).

\section{Vegetal material}

Leaves of B. basiloba A. Juss. were collected at Pratânia, SP, Brazil by Luiz Fernando R. de Almeida of the Botucatu Institute of Biosciences of São Paulo State University (IBBUNESP), Botucatu, SP, Brazil, and identified by Dr. Jose Clemente Campos, also of the IBB-UNESP. Exsiccates of voucher number 24163 can be found in the UNESP Herbarium, Botucatu.

\section{Ames mutagenicity assay}

The Salmonella mutagenicity assay was performed using the preincubation method, ${ }^{12}$ for 20-30 minutes with Salmonella typhimurium strains TA100, TA98, TA97a, and TA102, with and without metabolic activation. The metabolic activation mixture (S9 mix) was freshly prepared before each test using an Aroclor-1254-induced rat liver fraction purchased (lyophilized) from Moltox Molecular Toxicology Inc. (Boone, NC). The S. typhimurium strains were kindly provided by Dr. B. Ames of the University of California, Berkeley, CA.

Five different doses of the compounds extracted from the leaves of B. basiloba were evaluated in this assay; all of them were diluted in DMSO. The $\mathrm{CHCl}_{3}$ extract was tested in the mutagenicity assay at doses of $1.99,3.97,7.95,11.92$, and $15.90 \mathrm{mg}$ per plate, and the $\mathrm{MeOH}$ extract at doses of 3.65, $7.30,14.60,21.90$, and $29.20 \mathrm{mg}$ per plate. For the antimutagenicity assay the following concentrations were used: 0.99 , $1.99,3.97,7.95$, and $15.90 \mathrm{mg}$ per plate for the $\mathrm{CHCl}_{3} \mathrm{ex}-$ tract and $0.46,0.91,1.83,3.65$, and $7.30 \mathrm{mg}$ per plate with indirect mutagens and 1.82, 3.65, 7.30, 14.60 , and $21.90 \mathrm{mg}$ per plate with direct mutagens for the $\mathrm{MeOH}$ extract.

The concentrations used were based on the bacterial toxicity of each preparation, estimated in a preliminary test. In all sub- sequent assays, the upper limit of the dose range tested was either the highest nontoxic dose or the lowest toxic dose determined in this preliminary assay. Toxicity was apparent either as a reduction in the number of $\mathrm{His}^{+}$revertants or as an alteration in the auxotrophic background (i.e., background lawn).

Each concentration of the tested mixtures was added to $500 \mu \mathrm{L}$ of $\mathrm{pH} 7.4$ buffer or $500 \mu \mathrm{L}$ of $\mathrm{S} 9$ mix (to test the influence of metabolic activation) and $100 \mu \mathrm{L}$ of bacterial culture and then incubated at $37^{\circ} \mathrm{C}$ for $20-30$ minutes. After this time $2 \mathrm{~mL}$ of top agar was added, and the mixture was poured onto a plate containing minimal agar. The plates were incubated at $37^{\circ} \mathrm{C}$ for 48 hours, and the $\mathrm{His}^{+}$revertant colonies were manually counted. All the experiments were performed in triplicate.

The standard mutagens used as positive controls in experiments without S9 mix were NPD (10 $\mu \mathrm{g}$ per plate) for TA98 and TA97a, SAZ (1.25 $\mu \mathrm{g}$ per plate) for TA100, and daunomycin (3 $\mu \mathrm{g}$ per plate) for TA102. 2-Aminoanthracene $(0.125 \mu \mathrm{g}$ per plate) was used in the experiments with metabolic activation for all strains. DMSO served as the negative (solvent) control (100 $\mu \mathrm{L}$ per plate).

Statistical analysis was performed with the Salanal computer program, adopting the model of Bernstein et al. ${ }^{13}$ The mutagenic index was also calculated for each dose, as the average number of revertants per plate divided by the average number of revertants per plate of the negative (solvent) control. A sample was considered positive when the mutagenic index was $\geq 2$ for at least one of the tested doses and when the response was dose-dependent. ${ }^{14}$

\section{Ames antimutagenicity assay}

According to the methodology of preincubation in plates, developed by Maron and Ames, ${ }^{12}$ different concentrations of $\mathrm{MeOH}$ and $\mathrm{CHCl}_{3}$ extracts of B. basiloba were mixed with $0.1 \mathrm{~mL}$ of bacterial culture and the mutagenic agent (SAZ, NPD, MMC, $\mathrm{H}_{2} \mathrm{O}_{2}$, AFL, or $\mathrm{B}[a] \mathrm{P}$ ) and then incubated at $37^{\circ} \mathrm{C}$ for $20-30$ minutes. After incubation, $2 \mathrm{~mL}$ of top agar was added and supplemented with traces of histidine and biotin, and the content of each tube was lightly homogenized and poured onto a plate with minimum glucose agar. After the solidification of top agar, the plates were incubated for 48 hours at $37^{\circ} \mathrm{C}$, and the number of revertant colonies per plate was counted. The entire assay was performed in triplicate. The percentage of mutagenicity inhibition was calculated according to Tachino et al.,${ }^{15}$ where:

$$
\text { Inhibition }=\left(1-\frac{\text { revertants induced per plate }}{\begin{array}{c}
\text { revertants induced per plate } \\
\text { without inhibitor }
\end{array}}\right) \times 100
$$

A non-antimutagenic effect was considered when a value lower than $25 \%$ was obtained, a moderate effect when a value between $25 \%$ and $40 \%$ was obtained, and strong antimutagenicity at values greater than $40 \% .^{16}$ 
Cell viability was also determined for each antimutagenesis experiment to evaluate the potential bactericidal effect of the mutagens. The responses were considered cytotoxic when the percentage of sample survival was less than $60 \%$ of the total observed for the negative control. ${ }^{17}$

\section{Phytochemical analysis}

The powdered leaves $(800 \mathrm{~g})$ were extracted exhaustively and successively with $\mathrm{CHCl}_{3}$ and $\mathrm{MeOH}$ at room temperature, 48 hours for each solvent. The solvents were evaporated at $60^{\circ} \mathrm{C}$ under reduced pressure, providing the $\mathrm{CHCl}_{3}$ $(94.5 \mathrm{~g})$ and $\mathrm{MeOH}(79.3 \mathrm{~g})$ extracts, respectively. The yields (wt/wt) for the $\mathrm{CHCl}_{3}$ and $\mathrm{MeOH}$ extracts from the dried powders of B. basiloba leaves were $11.8 \%$ and $9.9 \%$, respectively.

A portion of $\mathrm{CHCl}_{3}$ extract $(30.0 \mathrm{~g})$ was filtered through a silica column $(15 \mathrm{~cm} \times 5.0$ i.d. $)$ to separate the compounds according to their polarity. This column initiated the elution with a pure $n$-hexane solvent, then with dichloromethane, and finally methanol. After evaporation of the remaining solvent, the hexane fraction (HF) $(0.4 \mathrm{~g})$, dichloromethane fraction (DF) (12.0 g), and $\mathrm{MeOH}$ fraction (MF) (10.3 g) were obtained, respectively. Part of the HF was chromatographed through a chromatography column (silica gel 60) with hexane $(100 \%)$ that produced an $n$-alkane mixture of $\mathrm{C}_{30}-\mathrm{C}_{34}$ consisting almost exclusively of triacontane $\left(\mathrm{C}_{30}\right)$ and dotriacontane $\left(\mathrm{C}_{32}\right)$. The MF was analogously fractionated by silica gel column chromatography using $\mathrm{CHCl}_{3}$ as an eluent, gradually increasing the polarity with $\mathrm{MeOH}$. The fractions were guided to provide ursolic and oleanolic acids. The DF resulted in an exclusive mixture of lupeol. These triterpenes were identified by comparison of their spectroscopic data with those reported in the literature. ${ }^{18}$

\section{n-Alkane identification: gas chromatography analyses}

Gas chromatography analyses were performed using a Varian (Walnut Creek, CA) CP 3380 gas chromatograph equipped with a fused silica CBP-5 capillary column $(25 \mathrm{~m} \times 0.33 \mathrm{~mm}$ i.d.; film thickness $0.5 \mathrm{~m}$ ) coupled to a flame ionization detector. Hydrogen was used as the carrier gas $(60 \mathrm{kPa})$, and the injection split ratio was 1:30. The injection temperature was $250^{\circ} \mathrm{C}$; the column temperature was maintained at $50^{\circ} \mathrm{C}$ for 1 minute and then increased to $300^{\circ} \mathrm{C}$ at $10^{\circ} \mathrm{C} /$ minute, where this temperature was maintained for 10 minutes; the detector temperature was $280^{\circ} \mathrm{C}$. $n$-Alkane standards and the fraction isolated from the $\mathrm{HF}$ of $1 \mu \mathrm{L}$ were manually injected using a $10-\mu$ L Hamilton (Reno, NV) syringe.

\section{Phytochemical screening and compound isolation from the $\mathrm{MeOH}$ extract}

The fresh $\mathrm{MeOH}$ extract proved positive for steroids, flavonoids, and proanthocyanidins. ${ }^{19}$

A portion $(10.0 \mathrm{~g})$ of the $\mathrm{MeOH}$ extract of $B$. basiloba was partitioned with a mixture of ethyl acetate $/ \mathrm{H}_{2} \mathrm{O}(1: 1$, $\mathrm{vol} / \mathrm{vol})$. The ethyl acetate fraction $(4.0 \mathrm{~g})$ was subjected to gel permeation chromatography on a Sephadex LH-20 (Pharmacia, Piscataway, NJ) column $(57 \times 3 \mathrm{~cm})$, eluted with $\mathrm{MeOH}$. Fractions $(15 \mathrm{~mL})$ were collected and checked by thin-layer chromatography on silica gel plates eluted with a mixture of $\mathrm{CHCl}_{3} / \mathrm{MeOH} / \mathrm{H}_{2} \mathrm{O}$ (80:18:2, by volume) and revealed either with natural products/polyethyleneglycol reagent or with anisaldehyde/sulfuric acid solution. ${ }^{20}$ Fractions $28-32(60.0 \mathrm{mg})$ were successively fractionated by column chromatography on silica gel (Merck, $10.0 \times 1.5 \mathrm{~cm}$ i.d.) eluted with $\mathrm{CHCl}_{3} / \mathrm{MeOH}$ (90:10, vol/vol), providing gallic acid and methyl gallate $(18.0 \mathrm{mg})$. Fractionation was realized by cellulose column chromatography $(12.0 \times 1.5$ i.d.) using $\mathrm{MeOH} / \mathrm{H}_{2} \mathrm{O}(80: 20)$ to yield the pure biflavonoid amentoflavone $(8.0 \mathrm{mg})$.

The nuclear magnetic resonance spectra in DMSO- $d_{6}$ were obtained using a Varian INOVA 500 spectrometer, operating at $500 \mathrm{MHz}$ for ${ }^{1} \mathrm{H}$ and $150 \mathrm{MHz}$ for ${ }^{13} \mathrm{C}$. Chemical shifts are given as $\delta(\mathrm{ppm})$ using trimethylsilane as an internal standard. Thin-layer chromatography analyses were performed on silica gel Si F254 (Merck) plates eluted with $\mathrm{CHCl}_{3} / \mathrm{MeOH}(80: 20$, vol/vol). The plates were visualized using ultraviolet light $(254 \mathrm{~nm})$.

\section{High-performance liquid chromatography analysis}

The high-performance liquid chromatography quantitative analysis of the $\mathrm{MeOH}$ extract was performed with a liquid chromatograph equipped with a ProStar 210 dual solvent pump, a ProStar 330 photodiode array detector (Varian, Palo Alto, CA), and a Rheodyne (Cotati, CA) model 7125 sample injector with a $20-\mu \mathrm{L}$ sample loop. The analytical column was a Phenomenex (Torrance, CA) Luna C2 RP18 $(250 \times 4.6 \mathrm{~mm}$ i.d.; particle size $5 \mu \mathrm{m})$ equipped with a Phenomenex Security Guard $(4.0 \times 2.0 \mathrm{~mm})$. The mobile phase compositions used were water (eluent $\mathrm{A}$ ) and acetonitrile (eluent B), both containing $0.05 \%$ trifluoroacetic acid. The gradient program was as follows: $27-34 \%$ B (3 minutes), 34-65\% B (42 minutes), and 65-100\% (5 minutes). Total run time was 50 minutes. The flow rate of the mobile phase was $1.0 \mathrm{~mL} /$ minute. Star LC Workstation software was used both for the operation of the detector and for data processing. These experiments permitted the identification of the flavonoids quercetin-3- $O-\left(2^{\prime \prime}-O\right.$-galloyl $)-\beta$-Dgalactopyranoside, quercetin-3-O-(2"-O-galloyl)- $\alpha$-L-arabinopyranoside, and quercetin. Compound identification was performed by comparison retention time, by spiking with known standards, and by comparison with previously isolated compounds under the same conditions. Methods using external standards were used to quantify each compound. For calibration curves, appropriate volumes of the standard stock solutions in rutin $(1.0 \mathrm{mg} / \mathrm{mL})$ were diluted with $75 \%$ $\mathrm{MeOH}$. For quantitation, peak areas were compared with the calibration curves. Flavonol glycosides and aglycones were calculated as rutin in the concentration range of 10-500 $\mu \mathrm{g} / \mathrm{mL} \quad\left(y=-4.81 \times 10^{5}+1.91 \times 10^{5} x, \quad R^{2}=0.9999\right.$, $n=7, \lambda=360 \mathrm{~nm})$. The high-performance liquid chro- 


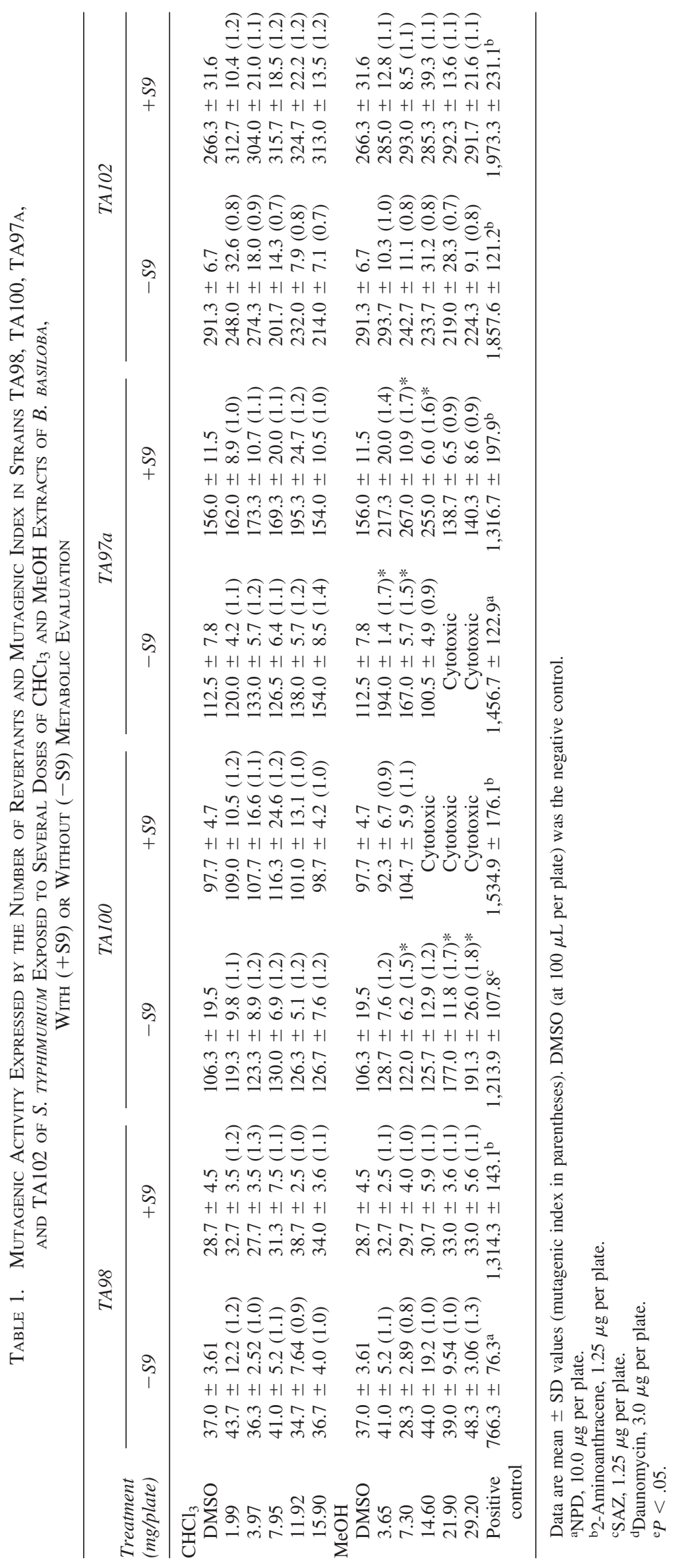


Table 2. Antimutagenic Activity Expressed by the Number of Revertants and Percentage of Inhibition of the MeOH Extract of B. basiloba with Direct Mutagenic Compounds, Using Strains TA97a,

TA98, TA100, AND TA102 of S. TYPHIMURIUM IN THE ABSENCE of S9

\begin{tabular}{|c|c|c|c|c|c|c|}
\hline \multirow[b]{2}{*}{ Strain } & \multirow[b]{2}{*}{ Mutagen } & \multicolumn{5}{|c|}{ Extract concentration (mg per plate) } \\
\hline & & 1.82 & 3.65 & 7.30 & 14.60 & 21.90 \\
\hline TA97a & $810 \pm 30^{\mathrm{a}}$ & $318 \pm 80$ (Tox $)$ & $335 \pm 9$ (Tox) & $94 \pm 30$ (Tox) & $45 \pm 8$ (Tox) & $22 \pm 3$ (Tox) \\
\hline TA98 & $504 \pm 9^{a}$ & $341 \pm 31(32)$ & $340 \pm 39(32)$ & $327 \pm 17(35)$ & $286 \pm 37(43)$ & $96 \pm 20(81)$ \\
\hline TA100 & $2,373 \pm 90^{\mathrm{b}}$ & $1,770 \pm 130(25)$ & $2,016 \pm 194(15)$ & $2,074 \pm 12(12)$ & $1,366 \pm 145(\mathrm{Tox})$ & $495 \pm 130($ Tox $)$ \\
\hline \multirow[t]{2}{*}{ TA102 } & $1,737 \pm 77^{c}$ & $1,507 \pm 7(13)$ & $1,558 \pm 85(10)$ & $1,265 \pm 24$ & $605 \pm 88(65)$ & $620 \pm 167(64)$ \\
\hline & $503 \pm 11^{\mathrm{d}}$ & $332 \pm 15(34)$ & $235 \pm 75(53)$ & $242 \pm 52(52)$ & $78 \pm 3$ (Tox) & $67 \pm 2($ Tox $)$ \\
\hline
\end{tabular}

Data are mean \pm SD values (percentage of inhibition). Tox, viability $<60 \%$.

aNPD, $10.0 \mu \mathrm{g}$ per plate.

bSAZ, $1.25 \mu \mathrm{g}$ per plate.

${ }^{\mathrm{c}} \mathrm{MMC}, 0.5 \mu \mathrm{g}$ per plate.

${ }^{\mathrm{d}} \mathrm{H}_{2} \mathrm{O}_{2}, 0.034 \mathrm{mg}$ per plate.

matography quantitative data were expressed as milligrams of flavonoid derivative per gram of solid extract (see Table $6)$.

\section{RESULTS}

\section{Mutagenic activity}

In the mutagenicity tests with the $\mathrm{MeOH}$ and $\mathrm{CHCl}_{3}$ extracts of the B. basiloba species, no positive mutagenicity was observed (Table 1). The results obtained for the $\mathrm{CHCl}_{3}$ extract presented an increase in the frequency of revertants in the strain TA100 (-S9), but the mutagenic index was not higher than 2. In the same strain, the $\mathrm{MeOH}$ extract became cytotoxic after metabolic activation at the highest three doses tested. In strain TA97a, cytotoxicity was also evident without metabolic activation.

\section{Antimutagenic activity}

The results obtained from studies on the antimutagenic potential of B. basiloba extracts are presented in Tables 2-5.

The $\mathrm{MeOH}$ extract was evaluated in strains TA97a, TA98, TA100, and TA102 using direct (NPD, SAZ, MMC, and $\mathrm{H}_{2} \mathrm{O}_{2}$ ) and indirect (AFL, $\mathrm{B}[a] \mathrm{P}$, and $\mathrm{H}_{2} \mathrm{O}_{2}$ ) mutagens. When the strain TA97a was used, this extract presented no reduction in the number of revertant colonies. However, in strain TA98, levels of reduction were obtained when tested with NPD (32-81\%; Table 2), AFL (68-81\%), and B[a]P $(66-82 \%)$ (Table 3). For strain TA100, the $\mathrm{MeOH}$ extract showed no protective effects against the action of SAZ (Table 2) but showed a strong protective effect when associated with AFL (84-89\%; Table 3). The protective action of the extract against the $\mathrm{H}_{2} \mathrm{O}_{2}$ mutagenic effect was evaluated in strain TA102, and it was concluded that the muta-

Table 3. Antimutagenic Activity Expressed by the Number of Revertants and Percentage of Inhibition of the MeOH Extract of B. basiloba with Indirect Mutagenic Compounds Using Strains ta97a,

TA98, TA100, AND TA102 of S. typhimurium in the Presence of S9

\begin{tabular}{|c|c|c|c|c|c|c|}
\hline \multirow[b]{2}{*}{ Strain } & \multirow[b]{2}{*}{ Mutagen } & \multicolumn{5}{|c|}{ Extract concentration ( $m g$ per plate) } \\
\hline & & 0.46 & 0.91 & 1.83 & 3.65 & 7.30 \\
\hline \multirow[t]{3}{*}{ TA97a } & $1,182 \pm 45^{\mathrm{a}}$ & $276 \pm 12$ (Tox) & $217 \pm 10($ Tox $)$ & $245 \pm 12$ (Tox) & $209 \pm 1.5$ (Tox) & $199 \pm 25$ (Tox) \\
\hline & $749 \pm 6^{\mathrm{b}}$ & $187 \pm 63$ (Tox) & $210 \pm 13($ Tox $)$ & $193 \pm 16$ (Tox) & $191 \pm 15$ (Tox) & $144 \pm 42$ (Tox) \\
\hline & & 1.82 & 3.65 & 7.30 & 14.60 & 21.90 \\
\hline \multirow[t]{2}{*}{ TA98 } & $613 \pm 16^{a}$ & $199 \pm 24(68)$ & $164 \pm 14(73)$ & $194 \pm 13(68)$ & $145 \pm 16(76)$ & $119 \pm 17(81)$ \\
\hline & $595 \pm 1^{b}$ & $201 \pm 8(66)$ & $169 \pm 12(72)$ & $163 \pm 8(73)$ & $163 \pm 10(73)$ & $110 \pm 9(82)$ \\
\hline \multirow[t]{2}{*}{ TA100 } & $1,627 \pm 77^{a}$ & $254 \pm 16(84)$ & $228 \pm 12(86)$ & $179 \pm 8(89)$ & $128 \pm 16$ (Tox) & $117 \pm 17$ (Tox) \\
\hline & $710 \pm 22^{b}$ & $95 \pm 3$ (Tox) & $96 \pm 11$ (Tox) & $86 \pm 7$ (Tox) & $53 \pm 3($ Tox $)$ & $13 \pm 2($ Tox $)$ \\
\hline TA102 & $614 \pm 18^{c}$ & $200 \pm 8(68)$ & $222 \pm 11(64)$ & $188 \pm 32($ Tox $)$ & $133 \pm 32($ Tox $)$ & $61 \pm 28$ (Tox) \\
\hline
\end{tabular}

Data are mean \pm SD values (percentage of inhibition). Tox, viability $<60 \%$.

${ }^{\mathrm{a} A F L}, 0.5 \mu \mathrm{g}$ per plate.

${ }^{\mathrm{b}} \mathrm{B}[\mathrm{a}] \mathrm{P}, 1 \mu \mathrm{g}$ per plate.

${ }^{\mathrm{c}} \mathrm{H}_{2} \mathrm{O}_{2}, 0.034 \mathrm{mg}$ per plate. 
Table 4. Antimutagenic Activity Expressed by the Number of Revertants and Percentage of Inhibition of $\mathrm{CHCl}_{3}$ Extract of B. basiloba with Direct Mutagenic Compounds Using Strains TA97a, TA98, TA100, AND TA102 of S. TYPhIMURIUM IN THE Absence of S9

\begin{tabular}{|c|c|c|c|c|c|c|}
\hline \multirow[b]{2}{*}{ Strain } & \multirow[b]{2}{*}{ Mutagen } & \multicolumn{5}{|c|}{ Extract concentration (mg per plate) } \\
\hline & & 0.99 & 1.99 & 3.97 & 7.95 & 15.90 \\
\hline TA97a & $810 \pm 30^{\mathrm{a}}$ & $203 \pm 46(75)$ & $197 \pm 20(76)$ & $178 \pm 17(78)$ & $179 \pm 16(78)$ & $193 \pm 10(76)$ \\
\hline TA98 & $504 \pm 9^{a}$ & $341 \pm 31(32)$ & $340 \pm 39(33)$ & $327 \pm 17(35)$ & $286 \pm 37(43)$ & $196 \pm 20(61)$ \\
\hline TA100 & $2,373 \pm 90^{\mathrm{b}}$ & $1,770 \pm 130(25)$ & $2,016 \pm 194(15)$ & $2,074 \pm 12(13)$ & $1,366 \pm 145(44)$ & $495 \pm 130(79)$ \\
\hline \multirow[t]{2}{*}{ TA102 } & $1,731 \pm 77^{\mathrm{c}}$ & $1,724 \pm 182(0.4)$ & $1,182 \pm 122(32)$ & $783 \pm 61(55)$ & $578 \pm 16(67)$ & $585 \pm 84(66)$ \\
\hline & $503 \pm 11^{\mathrm{d}}$ & $418 \pm 29(17)$ & $493 \pm 56(2)$ & $418 \pm 26(17)$ & $392 \pm 13(22)$ & $270 \pm 28(46)$ \\
\hline
\end{tabular}

Data are mean $\pm \mathrm{SD}$ values (percentage of inhibition). Tox, viability $<60 \%$.

${ }^{\mathrm{a} N P D}, 10.0 \mu \mathrm{g}$ per plate.

${ }^{\mathrm{b} S A Z}, 1.25 \mu \mathrm{g}$ per plate.

${ }^{\mathrm{c}} \mathrm{MMC}, 0.5 \mu \mathrm{g}$ per plate.

${ }^{\mathrm{d}} \mathrm{H}_{2} \mathrm{O}_{2}, 0.034 \mathrm{mg}$ per plate.

genic potential was significantly reduced independent of the presence or absence of metabolization. The levels of inhibition of the mutagenicity observed varied from $34 \%$ to $52 \%$ (Table 2) when tested in the absence of metabolic activation and around $60 \%$ when tested in the presence of metabolization (Table 3). Besides $\mathrm{H}_{2} \mathrm{O}_{2}$, a significant reduction on the number of revertant colonies also occurred in the same strain when the mutagen used was MMC (13-65\%; Table 2).

As for the $\mathrm{CHCl}_{3}$ extract, a general reduction in the mutagenic potential of the mutagens was observed. The levels of reduction of the mutagenicity were from $75 \%$ to $78 \%$ for NPD (Table 4) and $10 \%$ to $78 \%$ for B $[a] \mathrm{P}$ in strain TA97a (Table 5). For strain TA98, reductions varied from $32 \%$ to $61 \%$ for NDP (Table 4 ), $56 \%$ to $66 \%$ for $\mathrm{B}[a] \mathrm{P}$, and $66 \%$ to $74 \%$ for AFL (Table 5). In the case of TA100, the levels of reduction of the mutagenicity obtained with SAZ were $25-79 \%$ (Table 4 ), whereas for $\mathrm{B}[a] \mathrm{P}$ and AFL, toxicity was observed at all concentrations (Table 5). For strain TA102, when $\mathrm{H}_{2} \mathrm{O}_{2}$ was used without metabolization, the values ob- tained varied from $2 \%$ to $46 \%$ (Table 4 ), and in the presence of metabolization, values were around $60 \%$ (Table 5). When the mutagenic agent was MMC, the percentages of reduction were $0.4-67 \%$ (Table 4).

\section{Phytochemical analysis}

The HF of the $\mathrm{CHCl}_{3}$ extract from $B$. basiloba was analyzed by gas chromatography under the same condition as the aforementioned hydrocarbon standard, in order to obtain chromatograms and retention times. The results of hydrocarbon analyses showed the presence of a mixture of $n$-alkanes $\left(\mathrm{C}_{30}-\mathrm{C}_{34}\right)$. These consisted of only saturated straightchain hydrocarbons with triacontane $\left(\mathrm{C}_{30}\right)$ and dotriacontane $\left(\mathrm{C}_{32}\right)$ as the major components.

Fractionation of the DF resulted in the isolation of lupeol, and the MF provided ursolic and oleanolic acid.

The initial study of the $\mathrm{MeOH}$ extract of $B$. basiloba showed the presence of $(+)$-catechin and quercetin-3-O- $\alpha$ L-arabinopyranoside. ${ }^{6}$ In this work, the isolation or identifi-

Table 5. Antimutagenic Activity Expressed by the Number of Revertants and Percentage of Inhibition of the $\mathrm{CHCl}_{3}$ Extract of B. basiloba with Indirect Mutagenic Compounds, Using Strains TA97A, TA98, TA100, AND TA102 of S. typhimurium In the Presence of S9

\begin{tabular}{|c|c|c|c|c|c|c|}
\hline \multirow[b]{2}{*}{ Strain } & \multirow[b]{2}{*}{ Mutagen } & \multicolumn{5}{|c|}{ Extract concentration (mg per plate) } \\
\hline & & 0.99 & 1.99 & 3.97 & 7.95 & 15.90 \\
\hline \multirow[t]{2}{*}{ TA97a } & $749 \pm 6^{\mathrm{a}}$ & $67 \pm 10(10)$ & $289 \pm 14(61)$ & $164 \pm 14(78)$ & $178 \pm 9(76)$ & $165 \pm 13(78)$ \\
\hline & $1,128 \pm 45^{\mathrm{b}}$ & $276 \pm 12$ (Tox) & $217 \pm 10$ (Tox) & $245 \pm 12($ Tox $)$ & $209 \pm 1.5$ (Tox) & $199 \pm 2.5$ (Tox) \\
\hline \multirow[t]{2}{*}{ TA98 } & $595 \pm 1^{\mathrm{a}}$ & $259 \pm 11(56)$ & $212 \pm 4(64)$ & $208 \pm 13(65)$ & $258 \pm 13(56)$ & $197 \pm 9(66)$ \\
\hline & $613 \pm 16^{\mathrm{b}}$ & $211 \pm 2(66)$ & $183 \pm 18(70)$ & $186 \pm 7(70)$ & $179 \pm 4(70)$ & $158 \pm 4(74)$ \\
\hline \multirow[t]{2}{*}{ TA100 } & $710 \pm 22^{\mathrm{a}}$ & $350 \pm 15$ (Tox) & $253 \pm 16$ (Tox) & $85 \pm 16$ (Tox) & $74 \pm 11$ (Tox) & $23 \pm 2.3$ (Tox) \\
\hline & $1,627 \pm 75^{b}$ & $223 \pm 16$ (Tox) & $169 \pm 16($ Tox $)$ & $121 \pm 19$ (Tox) & $194 \pm 84$ (Tox) & $134 \pm 9$ (Tox) \\
\hline TA102 & $614 \pm 18^{c}$ & $254 \pm 8(59)$ & $269 \pm 31(56)$ & $267 \pm 6(57)$ & $234 \pm 13(62)$ & $261 \pm 24(57)$ \\
\hline
\end{tabular}

Data are mean $\pm \mathrm{SD}$ values (percentage of inhibition). Tox, viability $<60 \%$.

${ }^{\mathrm{a}} \mathrm{B}[\mathrm{a}] \mathrm{P}, 1 \mu \mathrm{g}$ per plate.

${ }^{\mathrm{b}} \mathrm{AFL}, 0.5 \mu \mathrm{g}$ per plate.

${ }^{\mathrm{c}} \mathrm{H}_{2} \mathrm{O}_{2}, 0.034 \mathrm{mg}$ per plate. 
cation of gallic acid, methyl gallate, the biflavonoid amentoflavone, quercetin-3-O-(2"-O-galloyl)- $\beta$-D-galactopyranoside, quercetin-3-O-(2"-O-galloyl)- $\alpha$-L-arabinopyranoside, and quercetin is described and is shown in Table 6.

\section{DISCUSSION}

Scientific studies that involve medicinal plants are being developed each day. They are important not only on an academic level, but are also economically and socially important. People have been using alternative medicinal treatments and plants for centuries, and the pharmaceutical and cosmetics industries are looking for natural sources of raw materials and active principles for their products.

Nevertheless, in many cases, people do not realize that treatments based on medicinal plants can cause serious risks to their health. Diagnoses are often inaccurate, and the symptoms of numerous serious diseases could be hidden by these types of treatment. ${ }^{21}$

Plants are composed of many chemical compounds, which can be cyto- or genotoxic and could be related to the development of tumors. ${ }^{22}$ Reid et al. ${ }^{23}$ evaluated the mutagenic effect of dichloromethane and $90 \% \mathrm{MeOH}$ extracts of 42 South African plants and observed that methanol extracts from whole plants of Helichrysum simillimum, Helichrysum herbaceum, and Helichrysum rugulosum demonstrated mutagenicity. Thus, the performance of assays for mutagenicity evaluation, as well as of other risks, is essential, given the consumption of natural products by the population. ${ }^{24}$

In this study, the mutagenicity and antimutagenicity of two different botanical extracts obtained from the leaves of $B$. basiloba were evaluated, since it is commonly used as a medicinal plant in Brazil. Using the Ames test, five different concentrations of a polar extract $(\mathrm{MeOH})$ and an apolar extract $\left(\mathrm{CHCl}_{3}\right)$ were evaluated.

As shown in Table 1 , the $\mathrm{CHCl}_{3}$ and $\mathrm{MeOH}$ extracts presented no mutagenicity in any of the strains used. The absence of a mutagenic response by plant extracts against $S$. typhimurium bacterial strains in the Ames assay is a posi-

Table 6. Content of the Main Flavonoids from B. basiloba

\begin{tabular}{lc}
\hline Compound & $\begin{array}{c}\text { Content }(\mathrm{mg} / \mathrm{g} \\
\text { of methanol } \\
\text { extract })^{\mathrm{a}}\end{array}$ \\
\hline NI & 2.20 \\
Quercetin-3-O- $\beta$-galactopyranoside & 3.82 \\
NI & 1.83 \\
Quercetin-3-O-(2"-O-galloyl)- $\beta$-D-galactopyranoside & 0.17 \\
Quercetin-3-O-(2"-O-galloyl)- $\alpha$-D-galactopyranoside & 2.97 \\
Quercetin & 0.53 \\
Amentoflavone & 1.79 \\
$\quad$ Total flavonoids & 13.31 \\
\hline
\end{tabular}

NI, not identified.

aFlavonoid contents determined by high-performance liquid chromatography-ultraviolet-photodiode array. tive step forward in determining the safe use of plants used in traditional medicine. Considering the popular use of this plant and the reduction in gastrointestinal motility, ${ }^{6}$ an effect that has been related to increased cancer risk because of longer exposure time to mutagens in the intestine, the negative mutagenic effect in bacterial systems is relevant.

Assays were then performed to evaluate the antimutagenic activity against direct and indirect mutagens. $\mathrm{B}[a] \mathrm{P}$ and AFL (indirect), SAZ, NPD, and MMC (direct), and $\mathrm{H}_{2} \mathrm{O}_{2}$ (direct and indirect) were included among these mutagens.

The extracts showed positive results when tested against the mutagenic agents, i.e., they presented antimutagenic potential for more than one strain and were efficient against different mutational mechanisms (frameshift, TA98 and TA97a; base pair substitution, TA100 and TA102; and antioxidative action, TA102). The highest value for the percentage of inhibition of the mutagenicity (89\%) was obtained with the $\mathrm{MeOH}$ extract, using the strain TA100 in the presence of AFL.

Phytochemical analysis of the $\mathrm{CHCl}_{3}$ extract in this work showed the presence of a mixture of $n$-alkanes $\left(\mathrm{C}_{30}-\mathrm{C}_{34}\right)$, of which triacontane $\left(\mathrm{C}_{30}\right)$ and dotriacontane $\left(\mathrm{C}_{32}\right)$ were the major components; in addition to these, lupeol, ursolic acid, and oleanolic acid were isolated.

The mutagenic or antimutagenic effects of $n$-alkanes have not been described in the literature, but lupeol, ursolic acid, and oleanolic acid are known for their antimutagenic activity. $^{25-28}$

Ursolic acid isolated from the ethanolic fraction of Eriobotrya japonica markedly and significantly decreased the numbers of $S$. typhimurium TA100 revertants per plate, thus showing antimutagenic activity. ${ }^{29}$

In addition, lupeol, a triterpene that has had its pharmacological properties approved, was present. According to the literature, lupeol presents anti-inflammatory, anti-arthritis, antimutagenic, antioxidative, and anticarcinogenic properties, ${ }^{30}$ as well as hepatoprotective properties against degenerative lesions caused by AFL. ${ }^{31}$

Phytochemical studies of the $\mathrm{MeOH}$ extract demonstrated the presence of $(+)$-catechin, quercetin-3- $O$ - $\alpha$-L-arabinopyranoside, quercetin, gallic acid, methyl gallate, and the amentoflavone. In previous studies by our group, using another species of Byrsonima, no mutagenic activity was observed for (+)-catechin, quercetin-3- $O$ - $\alpha$-L-arabinopyranoside, and methyl gallate; however, amentoflavone was positive for mutagenic activity. ${ }^{32}$ Despite the fact that this biflavonoid presented mutagenic activity, the amount of this compound found in the $\mathrm{MeOH}$ extract of $B$. basiloba $(1.79$ $\mathrm{mg} / \mathrm{g}$ of methanolic extract; Table 6) is much smaller than that found in Byrsonima crassa $(17.04 \mathrm{mg} / \mathrm{g}$ of methanolic extract) and Byrsonima intermedia $(13.70 \mathrm{mg} / \mathrm{g}$ of methanolic extract) extracts. ${ }^{33}$

Another aspect that should be considered is that quercetin also presents mutagenic activity ${ }^{34}$; however, in agreement with the present results the amount found in the $\mathrm{MeOH}$ extract is small $(0.53 \mathrm{mg} / \mathrm{g}$ of methanol extract) in relation to 
its glucoside derivatives (Table 6). The literature states that the glucoside quercetin presents significantly diminished pro-oxidant activity when compared to the pro-oxidant effect of quercetin aglycone. ${ }^{35}$

Methyl gallate presents no mutagenic potential. ${ }^{36}$ In addition, according to Dauer et al., ${ }^{37}$ catechin caused minimal damage to the genetic material of hepatocytes only at high concentrations. Martínez et al. ${ }^{36}$ also reported these data and showed that catechin was not capable of causing oxidative damage in specific strains of Escherichia coli. The same authors stated that gallic acid, also found in this vegetal extract, presented the capacity to cause oxidative damage, but that after metabolic activation, this property was no longer present.

Proanthocyanidins, condensed tannins, were isolated from the methanol extract of B. basiloba, and, according to Yamakoshi et al.,$^{38}$ an enriched fraction of these compounds obtained from grape seeds showed no mutagenic effects in the Ames test or on chromosome aberration in vitro or in the micronucleus of mouse cells. Dauer et al. ${ }^{37}$ reported that a fraction of proanthocyanidins obtained from Hamamelis virginiana caused breaks in hepatocyte DNA, which were detected using the comet assay; although, as stated in the same study, this tannin fraction also presented antigenotoxic activity in vitro.

Botanical extracts are used as medicine for several types of illness and may be used as chemopreventives in different parts of the world. Recently, Bunkova et al. ${ }^{39}$ demonstrated that green tea contains certain antioxidant substances, such as epigallocatechin, epicatechin, and catechin, among others, that are capable of reducing the level of mutagenicity to $70 \%$. Using green tea extract, which is rich in polyphenols (catechin, epicatechin), Geetha et al. ${ }^{40}$ showed antioxidative activity when the extract was tested against the oxidant potential of hydrogen peroxide in S. typhimurium TA102. In this study the antimutagenic activity of the $B$. basiloba extracts was observed in the presence of $\mathrm{H}_{2} \mathrm{O}_{2}$ for the TA102 strain that detects the effect of oxidative compounds.

Park et al. ${ }^{41}$ analyzed flavonoids in Rhus verniciflus extract and discovered efficiency in the antimutagenic test, with a considerable reduction in the level of mutagenicity promoted by aflatoxin. In general, this study showed that extracts of Byrsonima presented positive results for antimutagenicity and that this occurs in the presence of flavonoids.

In the present study, both $\mathrm{MeOH}$ and $\mathrm{CHCl}_{3}$ B. basiloba extracts were efficient at protecting bacterial genetic material against different types of damage caused by several mutagenic agents. A number of these agents, like AFL, $\mathrm{B}[a] \mathrm{P}$, and $\mathrm{H}_{2} \mathrm{O}_{2}$, are often found in the human daily diet and the environment.

All of these findings highlight that this plant extract could be useful for chemoprevention against damage produced by a variety of mutagenic compounds.

The occurrence rate of cancer is increasing worldwide, and the determination of chemopreventive or chemopro- phylaxis compounds is important regarding efforts to reduce the risk of cancer. ${ }^{42}$ An effect in vitro does not imply an effect in vivo, for example, because the responsible components may undergo mammalian metabolism modifying their activity and/or may not be bioavailable. A plant extract indicating antimutagenicity is not necessarily an anticarcinogen; however, it is a strong indication of possible anticarcinogenic properties that should stimulate further investigation. Antimutagenicity determination of plant extracts is also important in the discovery of new effective treatments for preventing the induction of cancer.

\section{ACKNOWLEDGMENTS}

The authors would like to thank the Fundação de Amparo à Pesquisa do Estado de São Paulo (FAPESP) for providing funds from the Biota-Fapesp Program and to the Conselho Nacional de Desenvolvimento Científico Tecnológico (CNPq) for grants given to W.V., E.A.V., and W.L.M.

\section{REFERENCES}

1. Roy M, Chakrabarty S, Sinha D, Bhattacharya RK, Siddiqi M: Anticlastogenic, antigenotoxic and apoptotic activity of epigallocatechin gallate: a green tea polyphenol. Mutat Res 2003;523524:33-41.

2. Aruoma OI: Nutrition and health aspects of free radicals and antioxidants. Food Chem Toxicol 1994;32:671-683.

3. De Flora S, D'Agostini F, Masiello L, Giunciuglio D, Albini A: Synergism between $\mathrm{N}$-acetylcysteine and doxorubicin in the prevention of tumorigenicity and metastasis in murine models. Int $J$ Cancer 1996;67:842-848.

4. Andreassi MG, Botto N, Colombo MG, Biagini A, Clerico A: Genetic instability and atherosclerosis: can somatic mutations account for the development of cardiovascular diseases? Environ Mol Mutagen 2000;35:265-269.

5. Lorenzi H: Árvores Brasileiras: Manual de Identificação e Cultivo de Plantas Arbóreas Nativas do Brasil. Instituto Plantarum, Nova Odessa, Brazil, 2002, p. 351.

6. Figueiredo MF, Michelin DC, Sannomiya M, Silva AP, dos Santos LC, de Almeida LFR, Souza-Brito ARM, Salgado HRN, Vilegas W: Avaliação química e da atividade anti-diarréica das folhas de Byrsonima cinera DC. (Malpighiaceae). Braz J Pharm Sci 2005;41:1-5.

7. Sannomiya M, Fonseca VB, da Silva MA, Rocha LR, dos Santos LC, Hiruma-Lima CA, Souza-Brito AR, Vilegas W: Flavonoids and antiulcerogenic activity from Byrsonima crassa leaves extracts. J Ethnopharmacol 2005;97:1-6.

8. Grey CE, Adlercreutz P: Ability of antioxidants to prevent oxidative mutations in Salmonella typhimurium TA102. Mutat Res 2003;527:27-36.

9. Ferguson LR, Lim IF, Pearson AE, Ralph J, Harris PJ: Bacterial antimutagenesis by hydroxycinnamic acids from plant cell walls. Mutat Res 2003;542:49-58.

10. Stagos D, Kazantzoglou G, Theofanidou D, Kakalopoulou G, Magiatis P, Mitaku S, Kouretas D: Activity of grape extracts from Greek varieties of Vitis vinifera against mutagenicity induced by bleomycin and hydrogen peroxide in Salmonella typhimurium strain TA102. Mutat Res 2006;609:165-175. 
11. Nogueira ME, Passoni MH, Biso FI, Longo MC, Cardoso CRP, Santos LC, Varanda EA: Investigation of genotoxic and antigenotoxic activities of Melampodium divaricatum in Salmonella typhimurium. Toxicol In Vitro 2006;20:361-366.

12. Maron DM, Ames BN: Revised methods for the Salmonella mutagenicity test. Mutat Res 1983;113:173-215.

13. Bernstein L, Kaldor J, McCann J, Pike MC: An empirical approach to the statistical analysis of mutagenesis data from the Salmonella test. Mutat Res 1982;97:267-281.

14. Varella SD, Pozzeti GL, Vilegas W, Varanda EA: Mutagenic activity in garbage from a aluminum products factory in Salmonella/microsome assay. Toxicol In Vitro 2004;18:895-900.

15. Tachino N, Guo D, Daswood WM, Yamane S, Larsen R, Dashwood R: Mechanisms of the in vitro antimutagenic action of chlorophyllin against benzo(a)pyrene: studies of enzyme inhibition, molecular complex formation and degration of the ultimate carcinogen. Mutat Res 1994;308:191-203.

16. Neigi PS, Jayaprakasha GK, Jena BS: Antioxidant and antimutagenic activities of pomegranate peel extracts. Food Chem 2003;80:393-397.

17. Vargas VM, Mota VE, Henriques JA: Mutagenic activity detected by the Ames test in river water under the influence of petrochemical industries. Mutat Res 1993;319:31-45.

18. Mahato SB, Kundu AP: ${ }^{13} \mathrm{C}$ NMR spectra of pentacyclic triterpenoids - a compilation and some salient features. Phytochemistry 1994;37:1517-1575.

19. Kokate CK, Purohit AP, Gokhale SB: Pharmacognosy. Nirali Prakashan, Pune, India, 1990, pp. 105-137.

20. Wagner HM, Bladt S, Zgainki EM: Plant Drug Analysis. Springer, Berlin, 1984, p. 320.

21. Elvin-Lewis M: Should we be concerned about herbal remedies. J Ethnopharmacol 2001;75:141-164.

22. Ames BN: Dietary carcinogens and anticarcinogens. Science 1983;221:1256-1264.

23. Reid KA, Maes J, Maes A, Van Staden J, De Kimpe N, Mulholland DA, Verschaeve L: Evaluation of the mutagenic and antimutagenic effects of South African plants. J Ethnopharmacol 2006; 106:44-50.

24. Marques RCP, Medeiros SRB, Dias CS, Barbosa-Filho JM, Agnez-Lima LF: Evaluation of the mutagenic potential of yangambin and of the hydroalcoholic extract of Ocotea duckei by the Ames test. Mutat Res 2003;536:117-120.

25. Niikawa M, Hayashi H, Sato T, Nagase H, Kito H: Isolation of substance from glossy privet (Ligustrum lucidum Ait.) inhibiting the mutagenicity of benzo (a) pyrene in bacteria. Mutat Res 1993;319:1-9.

26. Guevara AP, Amor E, Russel G: Antimutagens from Plumeria acuminata Ait. Mutat Res 1996;361:67-72.

27. Miyazawa M, Okuno Y, Imanishi K: Suppression of the SOS-inducing activity of mutagenic heterocyclic amine, Trp-P-1 by triterpenoid from Uncaria sinensis in the Salmonella typhimurium TA1535/ pSK1002 Umu test. J Agric Food Chem 2005;53:2312-2315.

28. Resende FA, Barcala CAMA, Faria MCS, Kato FH, Cunha WR, Tavares DC: Antimutagenicity of ursolic acid and oleanolic acid against doxorubicin-induced clastogenesis in BALB/c mice. Life Sci 2006;79:1268-1273.

29. Young HS, Chung HY, Lee CK, Park KI, Yokozawa T, Oura H: Ursolic acid inhibits aflatoxin $\mathrm{B}_{1}$-induced mutagenicity in a Salmonella assay system. Biol Pharm Bull 1994;17:990-992.

30. Saleem M, Afaq F, Adhami VM, Mukhtar H: Lupeol modulates NF- $\kappa \mathrm{B}$ and PI3K/Akt pathways and inhibits skin cancer in CD-1 mice. Oncogene 2004;23:5203-5214.

31. Preetha SP, Kanniappan M, Selvakumar E, Nagaraj M, Varalakshmi P: Lupeol ameliorates aflatoxin B-1-induced peroxidative hepatic damage in rats. Comp Biochem Physiol C Toxicol Pharmacol 2006;143:333-339.

32. Cardoso CR, Colus IMS, Bernardi CC, Sannomiya M, Vilegas W, Varanda EA: Mutagenic activity promoted by amentoflavone and methanol extract of Byrsonima crassa Niedenzu. Toxicology 2006;225:55-63.

33. Sannomiya M, Cardoso CRP, Figueiredo MF, Rodrigues CM, Santos LC, Santos FV, Serpeloni JM, Cólus IMS, Vilegas W, Varanda EA: Mutagenic evaluation and chemical investigation of Byrsonima intermedia A. Juss. leaf extracts. J Ethnopharmacol 2007;112:319-326.

34. Rietjens IMCM, Boersma MG, van der Woude H, Jeurissen SMF, Schutte ME, Alink GM: Flavonoids and alkenylbenzenes: mechanisms of mutagenic action and carcinogenic risk. Mutat Res 2005;574:124-138.

35. Heim KE, Tagliaferro AR, Bobilya DJ: Flavonoid antioxidants: chemistry, metabolism and structure-activity relationships. J Nutr Biochem 2002;13:572-584.

36. Martínez A, Urios A, Blanco M: Mutagenicity of 80 chemicals in Escherichia coli tester strains IC203, deficient in oxyR, and its oxyRQ parent WP2 uvralpkm101: detection of 31 oxidative mutagens. Mutat Res 2000;467:41-53.

37. Dauer A, Hensel A, Lhoste E, Knasmüller S, Mersch-Sundermann $\mathrm{V}$ : Genotoxic and antigenotoxic effects of catechin and tannins from the bark of Hamamelis virginiana L. in metabolically competent, human hepatoma cells (HEP G2) using single cell gel electrophoresis. Phytochemistry 2003;63:199-207.

38. Yamakoshi J, Saito M, Kataoka S, Kikuchi M: Safety evaluation of proanthocyanidin-rich extract from grape seeds. Food Chem Toxicol 2002;40:599-607.

39. Bunkova R, Marova L, Nemec M: Antimutagenic properties of green tea. Plant Food Hum Nutr 2005;60:25-29.

40. Geetha T, Garg A, Chopra K, Kaur IP: Delineation of antimutagenic activity of catechin, epicatechin and green tea extract. $\mathrm{Mu}$ tat Res 2004;556:65-74.

41. Park KY, Jung GO, Lee KT, Choi J, Choi MY, Kim GT, Jung HJ, Park HJ: Antimutagenic activity of flavonoids from the heartwood of Rhus verniciflua. J Ethnopharmacol 2004;90: 73-79.

42. Kundu JK, Mossanda KS, Na H-K, Surh Y-J: Inhibitory effects of the extracts of Sutherlandia frutescens (L.) R. Br. and Harpagophytum procumbens DC. on phorbol ester-induced COX-2 expression in mouse skin: AP-1 and CREB as potential upstream targets. Cancer Lett 2004;218:21-31. 